\title{
REVIEW
}

\section{Alternative states on coral reefs: beyond coral-macroalgal phase shifts}

\author{
Albert V. Norström ${ }^{1,2, *}$, Magnus Nyström ${ }^{1,2}$, Jerker Lokrantz ${ }^{1,2}$, Carl Folke ${ }^{2,3}$ \\ ${ }^{1}$ Natural Resource Management, Department of Systems Ecology, Stockholm University, SE-106 91 Stockholm, Sweden \\ ${ }^{2}$ Stockholm Resilience Centre, Stockholm University, SE-106 91 Stockholm, Sweden \\ ${ }^{3}$ The Beijer Institute, The Royal Swedish Academy of Sciences, SE-104 05 Stockholm, Sweden
}

\begin{abstract}
Degradation of coral reefs is often associated with changes in community structure where macroalgae become the dominant benthic life form. These phase shifts can be difficult to reverse. The debate on coral reef phase shifts has not focused on reports of coral reefs becoming dominated by other life forms following disturbance. A review of the primary and grey literature indicates that reefs dominated by corallimorpharia, soft corals, sponges and sea urchins can enter an alternative state as a result of a phase shift. Shifts can be triggered by pulse disturbances that cause largescale coral mortality, and may become stable as a result of positive feedback mechanisms. However, they may differ from the archetypical coral-macroalgae shift, depending on the factors driving the shift; whereas coral-macroalgae and coral-urchin shifts seem to be driven by loss of top-down control through overfishing, shifts to corallimorpharian, soft coral and sponge dominance seem more associated with changes in bottom-up dynamics. Understanding the differences and similarities in mechanisms that cause and maintain this variety of alternative states will aid management aimed at preventing and reversing phase shifts of coral reefs.
\end{abstract}

KEY WORDS: Phase shifts $\cdot$ Coral reefs $\cdot$ Alternative states $\cdot$ Corallimorpharia $\cdot$ Soft coral $\cdot$ Sponge $\cdot$ Urchin barren Resale or republication not permitted without written consent of the publisher

\section{INTRODUCTION}

Coral reefs worldwide have suffered substantial declines in coral cover and species diversity (Gardner et al. 2003, Bellwood et al. 2004, Bruno 2007), primarily due to the combined effects of overfishing (Jackson 1997), pollution (Dubinsky \& Stambler 1996), disease (Aronson \& Precht 2001) and climate change (Hughes et al. 2003, Hoegh-Guldberg et al. 2007). A growing body of literature suggests that these changes are often associated with coral reefs undergoing substantial phase shifts in community structure to a new state(e.g. Done 1992, Hughes 1994). Certain conditions may ultimately result in persistent alternative stable states (ASS), which are characterized by a different set of ecosystem processes, functions and feedback mechanisms (Scheffer et al. 2001, Mumby et al. 2007b). They may also cause alterations in the flow of ecosys- tem services, with consequences on livelihoods and societal development. Hence, understanding the features that drive phase shifts and maintain alternative states is fundamental from a human perspective (Folke et al. 2004).

Phase shifts on coral reefs are almost always associated with shifts from hard coral-dominated to macroalgae-dominated communities and have been the subject of several reviews (Done 1992, McCook 1999, Nyström et al. 2000, Szmant 2002, McManus \& Polsenberg 2004). Coral-macroalgal shifts have been reported from the Caribbean (Hughes 1994, Shulman \& Robertson 1996, McClanahan \& Muthiga 1998, Ostrander et al. 2000, Rogers \& Miller 2006), eastern Africa (Graham et al. 2006, Ledlie et al. 2007), Australia (Hatcher 1984) and the eastern Pacific (Maragos et al. 1985, Hunter \& Evans 1995). There are numerous reports of coral reefs becoming dominated by other 
organisms following a disturbance, but these have received less attention. For example, of $>200$ research articles listed in the ISI Web of Knowledge database using the keywords 'alternative states AND coral' and 'phase shifts AND coral' only 3 mention alternative states other than the macroalgal state (Done 1999, McClanahan et al. 2002, Bellwood et al. 2004). In these 3 cases, the 'other' alternative states are only briefly referred to, and a critical assessment of case studies and discussion of underlying mechanisms is lacking.

The ability to manage ecosystem changes associated with coral reef degradation would be greatly aided by better understanding (1) the potential range of phase shifts to other alternative states, (2) what causes them, and (3) which mechanisms lead to their establishment as ASS. We review the primary and grey literature and identify several other alternative states of coral reefs, highlighting the most robust cases of phase shifts to these states. Although these examples have been described previously, the information and data are synthesized to focus on the dynamics of phase shifts and alternative states; processes and mechanisms (e.g. human induced drivers and feedback mechanisms) behind their manifestation are discussed, emphasizing similarities with and differences to coral-macroalgae phase shifts. Finally, the implications of multiple alternative states for coral reef management are addressed.

\section{OVERVIEW OF ALTERNATIVE STATES ON CORAL REEFS}

We searched the literature utilizing ISI Web of Science, Google Scholar and Reefbase Online Library for reports of coral reefs undergoing transitions to communities characterized by a new dominant benthic organism (excluding shifts to macroalgae). To determine whether cases provided evidence of phase shifts and alternative states, it was necessary to propose reasonably broad definitions of these terms. A problem, recently stressed by Rogers \& Miller (2006), is that the term 'phase shift' is being broadly applied to cases where coral cover is lost from a reef but no major shift in dominant benthic assemblage occurs. We define phase shifts as extensive decreases in coral cover coinciding with substantial increases in some alternative benthic organism, due to a pulse or press disturbance, that have persisted $>5 \mathrm{yr}$. A minimum persistence time of 5 yr was used, as this is in accordance with the timeframe of studies describing cases of phase shifts from coral to macroalgal states (e.g. Shulman \& Robertson 1996, Ostrander et al. 2000, Graham et al. 2006, Ledlie et al. 2007). Where recent data pertaining to specific cases was lacking, publishing authors were contacted for information on current status. Reports of coral reefs becoming 'dominated' by an alternative organism assemblage following a disturbance or changes in environmental conditions are summarized in Fig. 1 and Table 1. We use 4 cases from Eilat (Israel), the Aldabra Atoll (Seychelles), Channel Cay (Belize) and Uva Island (Panama) (Cases 1, 4, 12, 14) as examples of phase shifts to corallimorpharian, soft coral, sponge and urchin barren states, respectively. These 4 cases provide quantitative data with substantial replication through time, which captures the shift in dominant benthic organism. The extent to which some reports of transitions to these states (Cases 2, 3, 5, 6, 8, 10, 13) constitute phase shifts is difficult to examine, as they (1) rely on anecdotal descriptions of coral reef conditions and/or (2) lack the temporal replication spanning through the pre- and post-disturbance status of the affected reef. In other cases the alternative organism had increased, but remained subdominant to hard coral cover (Cases 7, 9, 11). Cases where coral reefs have become dominated by sea anemones (Chen \& Dai 2004, Tkachenko et al. 2007) and ascidians (Bak et al. 1996) (Cases 15, 16) are not discussed as phase shifts or potential alternative states in this review, as they lacked replication over time or data on coral cover change, respectively.

\section{Corallimorpharian dominance}

Corallimorpharians are soft-bodied anthozoans that occur in a wide range of marine habitats. Anecdotal reports of coral reefs becoming dominated by corallimorpharians following extensive coral mortality were found from the western Indian Ocean (Rajasuriya \& Karunarathna 2000) and the Indo-Pacific (Ridzwan 1993). A recent study by Work et al. (2008) recorded substantial and spatially extensive increases in densities of the corallimorpharian Rhodactis howesii associated with a ship grounding on an isolated atoll (Palmyra) in the central Pacific Ocean. Qualitative and quantitative surveys around the ship in 2005 and 2007 found that the area of benthos dominated by $R$. howesii ( $>30 \%$ cover) had increased from approximately $500 \mathrm{~m}^{2}$ to $1 \times 10^{6} \mathrm{~m}^{2}$.

Long-term monitoring of the reef systems in the Eilat Coral Nature Reserve (Red Sea) provides evidence of a phase shift from coral to corallimorpharian dominance on the reef flat of the Japanese gardens reef. This shallow reef site was characterized by relatively high hard coral cover (36\%) until an extreme low-tide event in 1970 caused severe coral mortality (Loya 2004 and references therein) and reduced coral cover to $5 \%$ (Fig. 2a). Subsequent benthic community surveys (Fishelson 1970, Benayahu \& Loya 1977) showed no significant recovery of the hard coral community (fluc- 


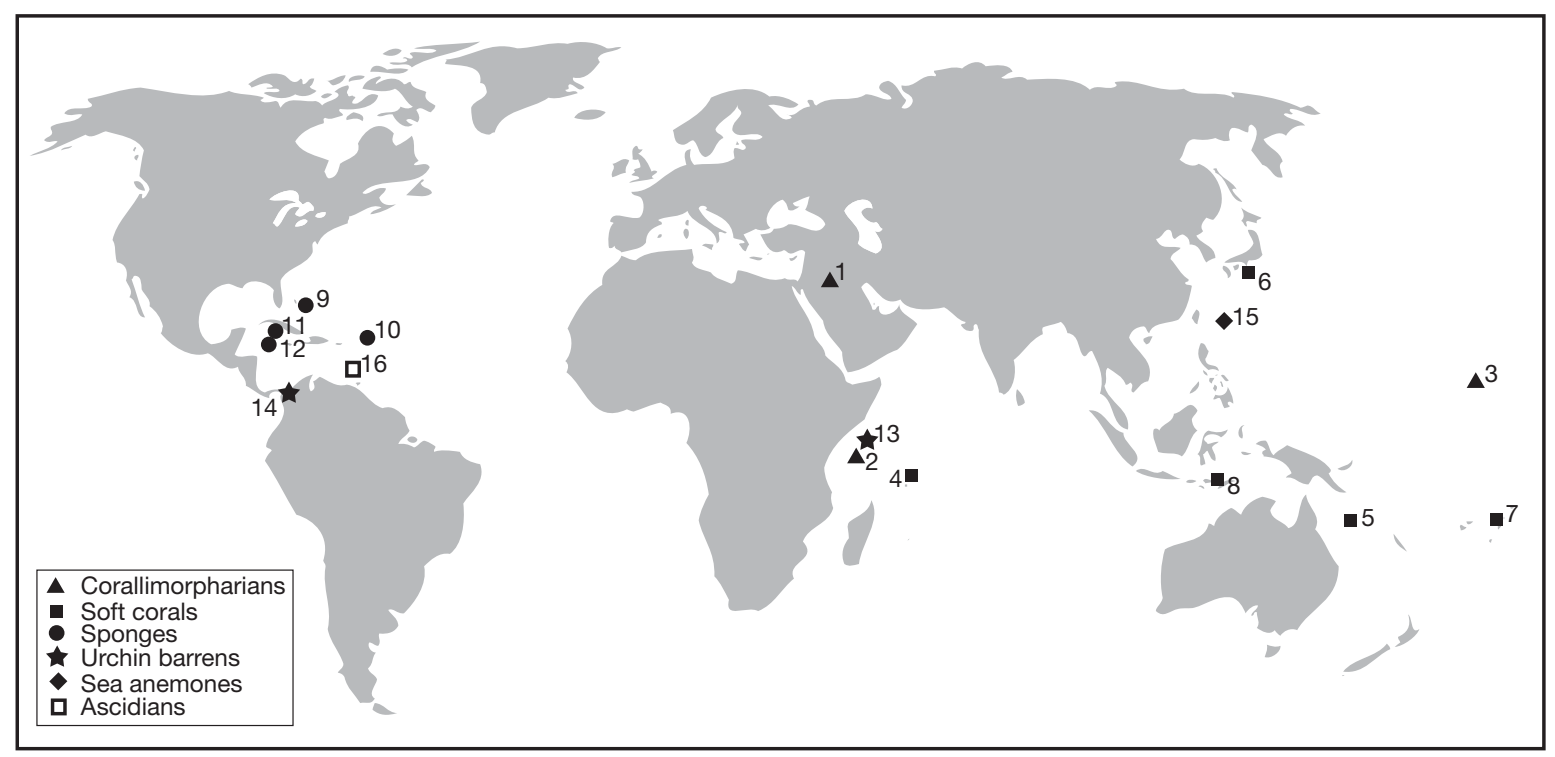

Fig. 1. Locations of coral reefs where transitions to other organism assemblages (excluding shifts to macroalgae) have occurred. See Table 1 for list of case studies

Table 1. Case studies of coral reefs becoming dominated by an alternative organism assemblage following a disturbance or changes in environmental conditions. n/a: anecdotal descriptions of community structure, or lack of quantitative data. Spatial extent of the shift: small $\left(<4 \times 10^{4} \mathrm{~m}^{2}\right)$, medium $\left(4 \times 10^{4}\right.$ to $\left.2 \times 10^{6} \mathrm{~m}^{2}\right)$, large $\left(>2 \times 10^{6} \mathrm{~m}^{2}\right)$. For symbols see Fig. 1

\begin{tabular}{|c|c|c|c|c|c|c|c|c|}
\hline \multirow[t]{2}{*}{$\begin{array}{l}\text { Transition type } \\
\text { (Location) }\end{array}$} & \multicolumn{2}{|c|}{$\begin{array}{c}\text { Coral } \\
\text { cover }(\%)\end{array}$} & \multicolumn{2}{|c|}{$\begin{array}{l}\text { Alternative } \\
\text { organism (\%) }\end{array}$} & \multirow[t]{2}{*}{ Scale } & \multirow[t]{2}{*}{ Period } & \multirow[t]{2}{*}{$\begin{array}{l}\text { Observed/suggested } \\
\text { disturbance described }\end{array}$} & \multirow[t]{2}{*}{ Source } \\
\hline & Initial & After & Initial & After & & & & \\
\hline \multicolumn{9}{|l|}{$\Delta$ Corallimorpharians } \\
\hline 1 Japanese Gardens, Israel & 36 & 10 & 0 & 27 & Small & 1969-1999 & $\begin{array}{l}\text { Extreme low tide, Oil } \\
\text { pollution, Siltation, } \\
\text { Eutrophication }\end{array}$ & $\begin{array}{l}\text { Chadwick-Furman \& } \\
\text { Spiegel (2000), Loya (2004) }\end{array}$ \\
\hline 2 Changuu reef, Zanzibar & 50 & 40 & $\mathrm{n} / \mathrm{a}$ & 15 & Small & 1997-1999 & $\begin{array}{l}\text { Mass bleaching, Siltation, } \\
\text { Eutrophication }\end{array}$ & $\begin{array}{l}\text { Muhando et al. (2002), } \\
\text { Kuguru et al. (2004) }\end{array}$ \\
\hline $\begin{array}{l}3 \text { Palmyra Atoll, US Line Islands } \\
\text { Soft corals }\end{array}$ & $\mathrm{n} / \mathrm{a}$ & $\mathrm{n} / \mathrm{a}$ & $<10$ & $>60$ & Medium & $1991-2007$ & Ship grounding & Work et al. (2008) \\
\hline 4 Aldabra Atoll, Seychelles & 35 & 11 & 3 & 14 & Medium & $1997-2004$ & Mass bleaching & Stobart et al. (2005) \\
\hline 5 Holbourne Island, Australia & $\mathrm{n} / \mathrm{a}$ & $\mathrm{n} / \mathrm{a}$ & $\mathrm{n} / \mathrm{a}$ & $\mathrm{n} / \mathrm{a}$ & Small & $1962-1987$ & Crown-of-thorns & Endean et al. (1988) \\
\hline 6 Okinawa, Japan & $\mathrm{n} / \mathrm{a}$ & 8 & $\mathrm{n} / \mathrm{a}$ & 19 & Small & $1970-1984$ & Crown-of-thorns, Siltation & Chou \& Yamazoto (1990) \\
\hline 7 Natadola Bay, Fiji & $\mathrm{n} / \mathrm{a}$ & $\mathrm{n} / \mathrm{a}$ & $\mathrm{n} / \mathrm{a}$ & $60^{\mathrm{a}}$ & Small & $1965-1969$ & $\begin{array}{l}\text { Siltation, Eutrophication, } \\
\text { Crown-of-thorns }\end{array}$ & Robinson (1971) \\
\hline $\begin{array}{l}8 \text { Komodo Park, Indonesia } \\
\text { Sponges }\end{array}$ & $\mathrm{n} / \mathrm{a}$ & 4.7 & $\mathrm{n} / \mathrm{a}$ & 11.3 & Small & $1950 s-1999$ & Blast fishing & Fox et al. (2003) \\
\hline 9 Florida Keys, USA & 11 & 7 & 1 & $12^{\mathrm{a}}$ & Large & $1996-2001$ & Siltation, Eutrophication & Ward-Paige et al. (2005) \\
\hline 10 La Parguera, Puerto Rico & $\mathrm{n} / \mathrm{a}$ & $<1$ & $\mathrm{n} / \mathrm{a}$ & 11 & Small & $1975-1992$ & $\begin{array}{l}\text { Mass bleaching, White- } \\
\text { band disease }\end{array}$ & $\begin{array}{l}\text { Williams et al. (1999), } \\
\text { Weil et al. (2002) }\end{array}$ \\
\hline 11 Carrie Bow Cay, Belize & 37 & 17 & 2 & 7 & Small & 1979-1998 & $\mathrm{n} / \mathrm{a}$ & Rützler (2002) \\
\hline $\begin{array}{l}12 \text { Channel Cay, Belize } \\
\star \text { Urchin barrens }\end{array}$ & 40 & 5 & 15 & 43 & Medium & $1997-2001$ & Mass bleaching & Aronson et al. (2002) \\
\hline 13 Diani, Kenya & 5 & 6 & 14 & $33^{\mathrm{a}}$ & Small & $1987-1992$ & Overfishing & $\begin{array}{l}\text { McClanahan \& Mutere } \\
\text { (1994) }\end{array}$ \\
\hline $\begin{array}{l}14 \text { Uva Island, Panama } \\
\downarrow \text { Sea anemones }\end{array}$ & 20 & 0 & 5 & 52 & Small & $1974-1994$ & Mass bleaching & Eakin (1996) \\
\hline $\begin{array}{l}15 \text { Tiao-Shi reef, Taiwan } \\
\square \text { Ascidians }\end{array}$ & $\mathrm{n} / \mathrm{a}$ & $\mathrm{n} / \mathrm{a}$ & $\mathrm{n} / \mathrm{a}$ & 32 & Small & $1992-2005$ & $\begin{array}{l}\text { Storm, Overfishing, } \\
\text { Pollution }\end{array}$ & $\begin{array}{l}\text { Chen \& Dai (2004), } \\
\text { Tkachenko et al. (2007) }\end{array}$ \\
\hline 16 Curacao, Netherlands Antilles & s n/a & $\mathrm{n} / \mathrm{a}$ & $22^{\mathrm{a}}$ & $197^{\mathrm{a}}$ & Large & $1978-1993$ & Pollution & Bak et al. (1996) \\
\hline
\end{tabular}




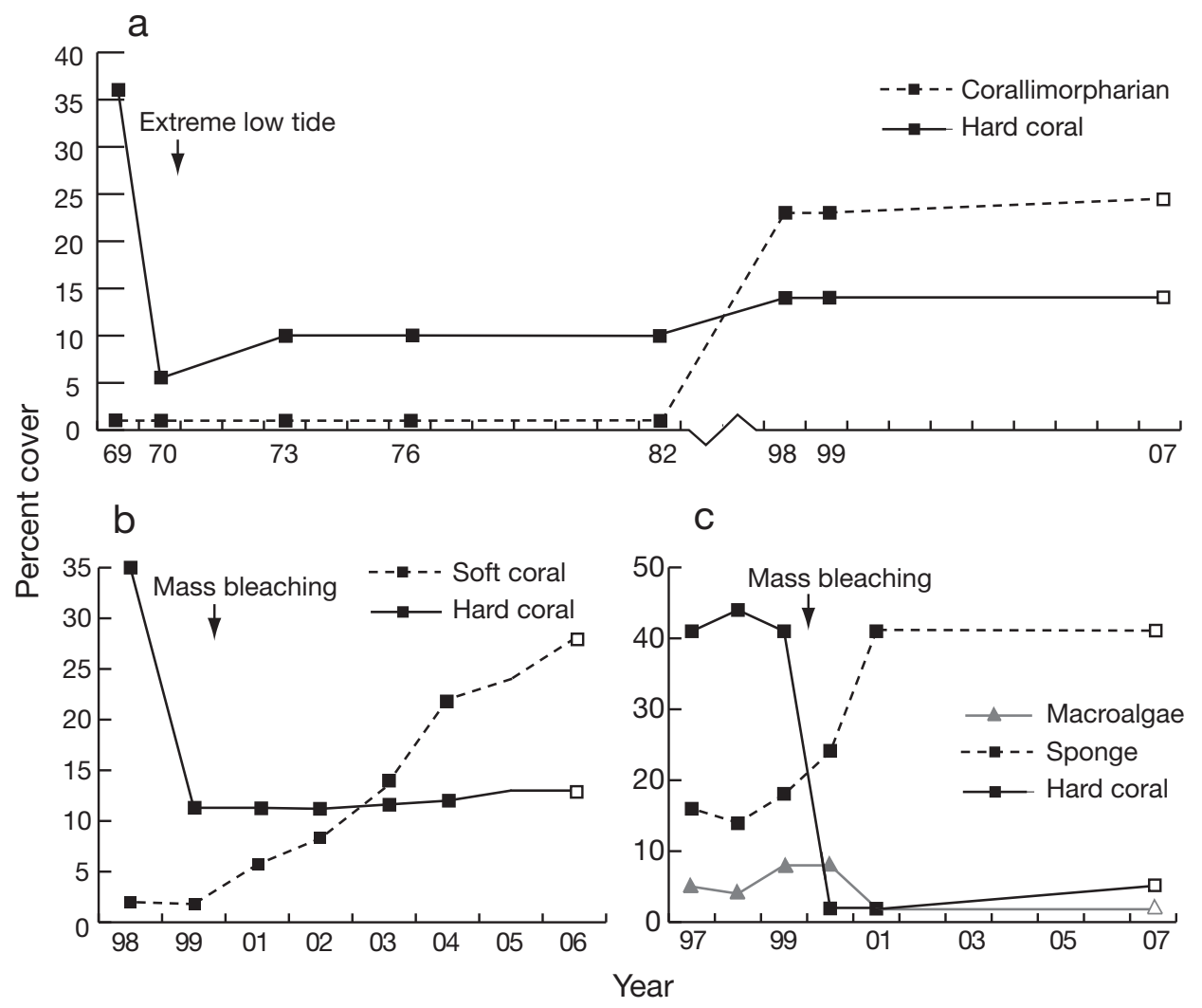

Fig. 2. Changes in benthic cover over time at (a) Japanese Gardens, Israel, (b) Aldabra Atoll, Seychelles, and (c) Channel Cay, Belize; (a) and (b) modified after Stobart et al. (2005), (c) modified after Aronson et al. (2004). $\mathbf{\Delta}$ published data; $\square \Delta$ authors' pers. comm

tuating between 5 and $15 \%$ cover) and did not report any corallimorpharian aggregations. This initial lack of recovery back to coral domination was likely caused by chronic oil spills in the area between 1970 and 1980 (Loya 2004), which could have affected different stages in the life-history of the corals and their recruitment capacity (Rinkevich \& Loya 1977, Bak 1987). This hypothesis is supported by the fact that nearby reef systems, unaffected by the chronic oil pollution, but simultaneously affected by the low tide event, quickly returned back to the hard coral state (Loya 2004). However, by 1998 a dramatic increase in the abundance of the corallimorpharian Rhodactis rhodostoma had occurred; it covered $29 \%$ of the substrate, making it the dominant benthic organism on the reef flat (Chadwick-Furman \& Spiegel 2000). Clonal replication of polyps and high sexual reproductive output likely contributed to the rapid expansion of $R$. rhodostoma aggregations on the reef flat, once founder colonies had settled (Chadwick-Furman \& Spiegel 2000, Chadwick-Furman et al. 2000). After it was established, it is possible that the numerous photoacclimation strategies possessed by $R$. rhodostoma (e.g. depth-dependent zooxanthellae abundance and identity, host-mediated protection of zooxanthellae and dispersal of excess light energy through non- photochemical quenching) allowed it to thrive in the highly irradiated shallow reef environments of the northern Red Sea (Kuguru et al. 2007, 2008). Furthermore, Kuguru et al. (2008) found that individuals of $R$. rhodostoma hosting only 1 type of zooxanthellae genotype regulate photosynthetic efficiency better than other corallimorpharian species that host multiple algal genotypes, when exposed to high light stress. They suggested that corallimorpharians harboring 1 type of zooxanthellae symbiont are more resilient to high light stress compared to cnidarians hosting multiple types of symbionts. Surveys from 2007 indicate that $R$. rhodostoma have increased further in abundance and hard coral cover remains at the low levels previously reported (N.E. Chadwick pers. comm.). Consequently, this transition from corals to corallimorpharians appears to be a long-term change of $10 \mathrm{yr}$ or more, and continues to persist (Fig. 2a).

\section{Soft coral dominance}

Soft corals are a diverse and common benthic component of coral reefs in the Indian Ocean (Reinicke \& Van Ofwegen 1999), Red Sea (Riegl \& Piller 1999), Indo-Pacific (Benayahu 1997, Benayahu et al. 2004) 
and on the Great Barrier Reef (Dinesen 1983, Ninio et al. 2000). Early ecological models predicted that soft corals would increase in abundance and dominate the reef benthos following scleractinian mortality caused by, for example, crown-of-thorns outbreaks (Bradbury \& Mundy 1989). A number of anecdotal studies lend some support to these predictions, reporting that species of the families Alcyoniidae (especially the genus Sinularia) have come to dominate coral reefs locally in the western Indian Ocean (Muhando \& Mohammed 2002) and the Indo-Pacific (Robinson 1971, Nishihira \& Yamazoto 1974, Endean et al. 1988, Chou \& Yamazato 1990, Fabricius 1998). Fox et al. (2003) reported locally high abundances of the soft coral Xenia sp. (up to $80 \%$ ) on coral rubble patches that have suffered chronic disturbance through blast fishing.

Another example is from the Aldabra Atoll in the southern Seychelles, which has undergone a phase shift from scleractinian to soft coral dominance. Following mass bleaching in 1997-1998, the Aldabra reef suffered large-scale mortality (Fig. 2b), as did most shallow reef communities in the western Indian Ocean (Obura 2002). On the outer reef, 66\% of the shallow water $(10 \mathrm{~m})$ hard corals were killed, with $38 \%$ mortality in the deeper water $(20 \mathrm{~m})$ communities (Stobart et al. 2002). Until 1997-1998, soft corals comprised $3 \%$ of the benthos, and showed moderate levels of bleaching and mortality following the bleaching event (Teleki et al. 2000). Annual monitoring of permanent transects from 1999 to 2006 indicated no recovery of hard corals, with abundances remaining stable at around $12 \%$ cover. The only group exhibiting significant changes in abundance is the soft coral genus Rhytisma, which increased from 0 to $26 \%$ cover, resulting in soft corals becoming the dominant benthic group (28\% cover) in the shallow coral communities by 2004 (Buckley et al. 2004, Stobart et al. 2005, B. Stobart pers. comm.).

\section{Sponge dominance}

Reports of shifts from coral to sponge dominated reefs have mostly involved species from the genera Cliona and Chondrilla. During the past 3 decades, reports from the Caribbean have indicated increased abundances of bioeroding clionid sponges, especially on reefs where scleractinians have suffered high mortality (Antonius \& Ballesteros 1998, Lopez-Victoria \& Zea 2004). In the late 1970s, the reefs surrounding La Parguera on the southwestern tip of Puerto Rico were heavily dominated by the corals Acropora cervicornis and A. palmata. The compounding effects of disease, siltation, eutrophication, and hurricanes led to a dramatic decline in their abundances (Weil et al. 2002 and references therein). Subsequently, Cliona langae monopolized much of the shallow reef substrate that was formerly occupied by live Acropora sp., rapidly overgrowing remaining coral colonies and fragments, and preventing coral recovery. Live hard coral cover is now $0.3 \%$, whereas cover of C. langae is $11 \%$ (Williams et al. 1999). A similar scenario seems to be unfolding in the Florida reef tract (USA). Annual trends in clionid sponge abundances and coral cover within the Florida Keys National Marine Sanctuary (FKNMS) were assessed between 1996 and 2001 (Ward-Paige et al. 2005). Overall coral cover declined from 11 to $7 \%$, while Cliona delitrix and C. lampa abundances increased from 1 to 12 individuals per transect. However, a similar assessment of coral community change in the FKNMS between 1996 and 2000 found no change in percentage sponge cover during that period (Maliao et al. 2008). Ward-Paige and coworkers argue that counts of individual sponges per transect were used in their analysis, since percentage cover does not adequately capture abundance of clionid sponges due to their growth forms, and this can explain the contrasting results between the studies.

A well documented example of a coral-sponge shift comes from the Channel Cay reef complex, in the central section of the Belize barrier reef. In December 1998 severe bleaching resulted in catastrophic mass mortality of scleractinian corals (Fig. 2c), with hard coral cover dropping from 40 to $5 \%$ in just a few months (Aronson et al. 2000). The free substrate was quickly colonized by the chicken liver sponge (Chondrilla nucula), increasing total sponge cover from 15 to $43 \%$ between 1998 to 2001 (Aronson et al. 2002). This shift occurred despite high abundances of spongivorous fishes such as Pomacanthus arcuatus (Rützler et al. 2000, Wulff 2000). In 2007, total hard coral cover was $5 \%$, and C. nucula remained the dominant component of substratum cover (R. B. Aronson pers. comm.). An interesting feature of the Channel Cay example is that macroalgal abundances remained low, in sharp contrast to other sections of the Belize barrier reef, which underwent coral-macroalgae shifts following the same bleaching event (McClanahan \& Muthiga 1998). This has been attributed to the high local abundance of the grazing urchin Echinometra viridis in the central section of the Belize barrier reef, which kept macroalgae in check (Aronson et al. 2002).

\section{Urchin barren states}

Herbivorous sea urchins can play 2 substantially different roles in the dynamics of phase shifts on coral reefs because their functional impact can be densityspecific. On the one hand, they promote coral reef resilience by controlling algal cover (Carpenter 1986, 
Mumby et al. 2007a). On the other hand, in high abundances echinoids can remove substantial amounts of calcium carbonate from the living and dead coral framework, and may also prey on coral juveniles. In the western Indo-Pacific and the eastern Pacific, hyperabundance of sea urchins has shifted certain coral reefs to urchin barrens; in these sea urchin dominated states, the rate of bioerosion has surpassed net reef accretion (Eakin 1996, Glynn 1997).

The strongest evidence for scleractinian-urchin barren shifts is found in long-term studies on the low diversity reef of Uva Island, on the Pacific coast of Panama. Elevated temperature associated with an exceptionally strong El Niño-Southern Oscillation (ENSO) event in 1982-1983 caused extensive coral mortality ( $50 \%)$ on Uva Island, as on most other coral reefs of the equatorial eastern Pacific (Glynn 1985). Subsequently, density of the herbivorous sea urchin Diadema mexicanum increased from 3 to 50 ind. $\mathrm{m}^{2}$ on the reef base and 20 ind. $\mathrm{m}^{2}$ on the fore reef. Coral recruitment was hindered by predation by other corallivores and an extreme low-tide event caused by La Niña (Eakin 2001). Sea urchin density remained high until the late 1990s (Eakin 2001), but by 2000 it declined to the levels before the 1982-1983 ENSO event. However, the carbon budget of Uva Island reef has remained negative and erosive $(-3000$ to -18000 $\mathrm{kg} \mathrm{CaCO}_{3} \mathrm{yr}^{-1}$ ), from a net production of $>8600 \mathrm{~kg}$ $\mathrm{CaCO}_{3} \mathrm{Yr}^{-1}$ before 1982-1983 (Eakin 2001).

\section{DISCUSSION}

\section{Environmental and human drivers of phase shifts}

Evidence of coral-macroalgae phase shifts from field data has been supplemented by experimental (Hughes et al. 2007), theoretical (Knowlton 1992, McManus \& Polsenberg 2004) and modeling (Mumby et al. 2007b) work describing the processes leading to the shift. Theoretical and modeling work suggest that a loss of resilience through human interventions, such as overfishing of herbivorous fishes, precedes phase shifts from coral to macroalgal states (Mumby 2006), making the system progressively vulnerable to pulse disturbances (Nyström et al. 2000). The loss of key herbivores has been suggested to be the strongest driver, and although nutrient overloads can contribute to reef degradation, they are unlikely to lead to phase shifts unless herbivory is unusually or artificially low (see reviews by McCook 1999, Szmant 2002). Hughes et al. (2007) experimentally manipulated the densities of large herbivorous fish over a $3 \mathrm{yr}$ period on reefs that had recently suffered a large-scale loss of coral cover and diversity; algal abundance remained low, whereas coral cover almost doubled, in areas where fishes were abundant. In contrast, exclusion of large herbivorous fishes caused an explosion of macroalgae which prevented reestablishment of corals. While the cases of phase shifts to corallimorpharian, soft coral or sponge dominance highlighted in Fig. 2 were triggered by pulse disturbances (mass bleaching or low-tide events), it is difficult to determine whether a loss of resilience preceded this proximal trigger. Loya (2004) suggested that chronic oil pollution reduced resilience and hindered coral recovery at the Japanese Gardens reef following the 1970 low tide event. However, no substantial human influences have been recorded in the cases of sponge and soft coral phase shifts at Channel Cay and Aldabra Atoll. Aldabra Atoll has escaped most direct human impacts, due to its isolated geographic position and its status as a UNESCO world heritage site. The Channel Cay rhomboid reef complex underwent dramatic changes in coral community structure prior to the sponge phase shift; Agaricia tenuifolia replaced Acropora cervicornis as the dominant hard coral at shallow depths, following a regionwide outbreak of white-band disease (WBD) (Aronson et al. 1998). The link, however, between WBD and human activities remains unclear (Lesser et al. 2007). Furthermore, there is no obvious reason as to why this would have led to an overall increased vulnerability of the Channel Cay reefs to the bleaching event of 1998.

On the other hand, correlative data suggest that transitions to corallimorpharian, sponge, soft coral and urchin dominated reefs are facilitated in human influenced environments. High corallimorpharian abundances are correlated with high sedimentation and nutrient levels (Muhando et al. 2002, Kuguru et al. 2004) and high irradiance and increased temperature (Kuguru et al. 2007). Transitions to sponge dominated reefs may also be linked to declining water quality; for example, Holmes et al. (2000) found a positive correlation between eutrophication and high boring sponge abundances on live massive corals and branching rubble at 9 Indonesian reefs. Moreover, patterns of coral decline and clionid sponge increase in the Florida reef tract are correlated to high levels of sewage stress (Rose \& Risk 1985, Ward-Paige et al. 2005). Experimental studies suggest that top-down control (spongivory) also plays an important role in regulating the abundances of certain aggressive sponges such as Chondrilla nucula (Hill 1998). However, the sponge phase shift at Channel Cay involved C. nucula and occurred in the presence of high levels of spongivorous fishes, such as the gray angelfish (Wulff 2000). Alterations in top-down control have been suggested to drive coral-urchin barren shifts, in that the overexploitation of sea urchin predators allows urchin populations to grow unchecked (McClanahan \& Shafir 
1990, McClanahan 1995). Studies from Kenya (McClanahan \& Mutere 1994) have shown a strong correlation between high abundances of the urchin Echinometra mathei and low coral cover at heavily overfished reefs. The lack of temporal data obscures the causal link between fishing pressure, increased urchin abundance and decrease in coral cover, and further experimentation is necessary to distinguish the actual effect of fishing from other drivers potentially altering the coral communities. The substantial amount of anecdotal evidence indicates that phase shifts to sponge, corallimorpharian and soft coral dominance are driven by bottom-up forcing linked to declining water quality. In contrast, sea urchin barrens seem to be primarily driven by a loss of top-down control, as is the case with phase shifts to macroalgae. However, although many of these 'natural experiments' and correlative comparisons have the advantage of greater generality than small-scale experiments, due to the larger spatial and temporal scales involved, they do not demonstrate causality; correlations may be coincidental or consequential, rather than directly causal. More direct experimental evidence is required to shed light on the primary drivers that lead to the different phase shifts.

\section{Alternative states vs. alternative stable states (ASS)}

Evidence of reversal from macroalgae phase shifts is limited to a few shallow sites that have witnessed signs of recovery (i.e. decline of macroalgae, increase in coral cover); these are correlated with increased abundance of the herbivorous sea urchin Diadema antillarum (Carpenter \& Edmunds 2006, Idjadi et al. 2006). Theory suggests that when a phase shift to a macroalgae-dominated alternative state has occurred, the creation of positive feedback processes and chronic changes in environmental conditions such as the loss of herbivory can result in persistent macroalgal ASS that exhibit hysteresis (Knowlton 1992, Mumby et al. 2007b, Nyström et al. 2008). Hysteresis implies that state variables (e.g. herbivore biomass) in shifted ecosystems need to be restored to levels way beyond the threshold values that initially caused the shift (O'Neill 1998, Suding et al. 2004). Thus, once the system has shifted to a new stable state, simply removing the stress will not automatically produce recovery, as witnessed in local experimental studies on coral reefs. For example, McClanahan et al. (2000) showed that 're-setting' Belize lagoon patch reefs by manually removing algae was not sufficient to shift the algaedominated state, even in protected ('no-take') reefs where grazing fish were abundant. Feedback mechanisms reinforcing the macroalgal stable state could be manifest as follows: A sudden loss of coral cover liberates space for algal colonization and can lead to a subsequent increase in macroalgae abundance if there is a low abundance of herbivores or if algal proliferation is rapid enough to overwhelm the grazing capacity of the standing stock of herbivores (Williams et al. 2001). The increase in macroalgal abundance leads to the physical preemption of coral settlement space and a higher frequency of coral-macroalgal interactions. This can further affect coral recruitment (Kuffner et al. 2006), reduce coral growth rates (Tanner 1995) and result in additional coral mortality (Smith et al. 2006, Box \& Mumby 2007), which further reinforce the macroalgal state. It is plausible that similar feedback mechanisms, generated by quick monopolization of open space and subsequent inhibition of coral recruitment and coral growth, reinforce soft coral, corallimorpharian and sponge dominance (Fig. 3). Fox et al. (2003) found that soft corals of the genus Xenia dominating 2 heavily degraded reefs in eastern Indonesia inhibited coral growth and pre-empted coral settlement space. Other experimental studies show that soft corals exhibit allelochemical mechanisms that can kill corals (Sammarco et al. 1983) and hinder coral recruitment (Maida et al. 1995, Atrigenio \& Aliño 1996) and growth (Aliño et al. 1992). Corallimorpharians also damage and overgrow neighbouring corals (Chadwick 1987, Langmead \& Chadwick-Furman 1999) and possess reproductive strategies that allow rapid colony doubling times (Chadwick-Furman \& Spiegel 2000). Similarly, sponges not only have the ability to colonize free substrate quickly, but are capable of overgrowing living coral through physical (Lopez-Victoria et al. 2006) and chemical mechanisms (Pawlik et al. 2007). Although the proposed positive feedback mechanisms described for soft coral, corallimorpharian and sponge stable states are based on a few small-scale experiments, they should stimulate further work on the mechanisms that could be reinforcing these ASS. The existence of such feedback mechanisms would explain why soft coral and sponge dominance persist on reefs such as Aldabra Atoll and Channel Cay, with no obvious external environmental change.

\section{Increased frequency of phase shifts and potential consequences}

In a seascape increasingly influenced by human activities (Halpern et al. 2008, Mora 2008), recovery of coral reef systems following a phase shift is made even more difficult, and the manifestation of ASS more probable. The area of substratum opening up due to mass bleaching, coral disease and increased frequency of severe storms is predicted to increase (Harvell et al. 


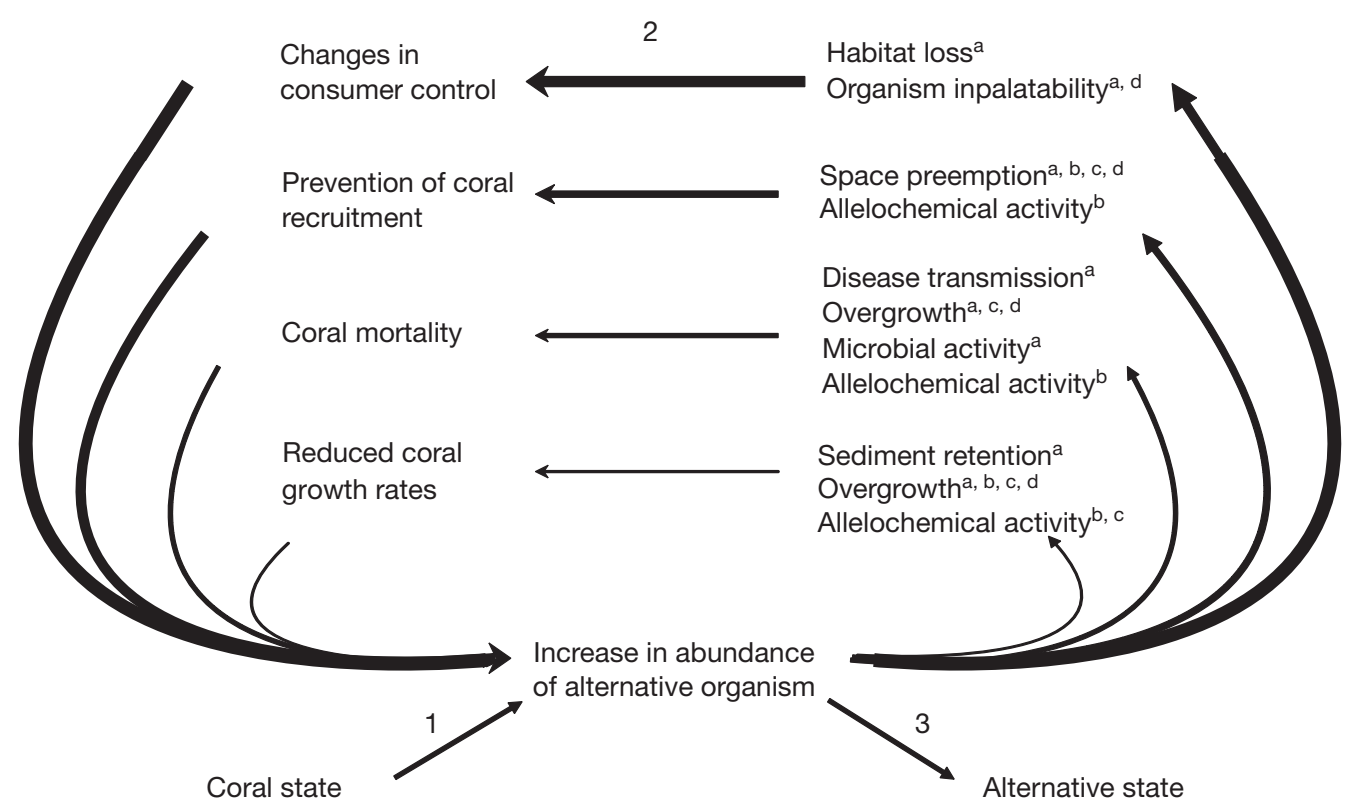

Fig. 3. Potential feedback mechanisms reinforcing the macroalgal, soft coral, corallimorpharian and sponge states. (1) Space opening up due to coral mortality leads to an increase in the abundance of the alternative organism. (2) Positive feedback mechanisms, which directly or indirectly reinforce the (3) alternative state are attributed to ${ }^{a}$ macroalgae, ${ }^{b}$ soft corals, ${ }^{\mathrm{c}}$ corallimorpharia, ${ }^{\mathrm{d}}$ sponges

2002, Wilkinson 2004), alongside increases in ocean temperature (IPCC 2007), nutrient levels (Tilman 1999) and overfishing (Wilkinson 2004). Conversely, many corallimorpharian, sponge, soft coral and sea urchin species either exhibit traits that provide a physiological tolerance toward the environmental conditions caused by anthropogenic disturbance regimes (such as eutrophication, higher temperatures and sedimentation), or they are released from top-down control, due to overfishing. This could result in an increased occurrence and persistence of the discussed alternative states, and to their manifestation over extensive spatial scales. None of the alternative states described in this paper have been manifest over the extensive spatial scales that have been reported for some cases of coral-macroalgae phase shifts (e.g. Hughes 1994). However, Ward-Paige et al. (2005) documented increasing abundances of Cliona delitrix and C. lampa throughout the Florida reef tract between 1996 and 2001, and clionid sponges dominate large parts of the reef seascape in the central Caribbean region (Antonius \& Ballesteros 1998, Williams et al. 1999, Rützler 2002, Lopez-Victoria \& Zea 2004). One determinant of the spatial scale of phase shifts lies in the scale and nature of the disturbance causing the shift (deYoung et al. 2008). Additionally, other authors suggest that the spatial context of ecosystems and the degree of connectivity between patches can have implications for the likelihood of large-scale phase shifts (Petraitis \& Latham 1999, Van Nes \& Scheffer 2005). Monitoring the occurrence and spatial distribution of local phase shifts might help to anticipate impending potentially catastrophic (i.e. large-scale) phase shifts (Nyström et al. 2008). The ability of a coral reef to return to coral dominance following a disturbance is highly dependent on its surroundings; for example, the distribution and interactions of functional groups between reefs and/or associated habitats (e.g. mangroves and seagrass beds) and the import of larvae from outside areas (Nagelkerken et al. 2002, Hughes et al. 2005, Mumby \& Hastings 2008). This spatial resilience (Nyström \& Folke 2001) may be jeopardized as more local reefs shift to ASS, further hampering future coral recovery.

\section{CONCLUSIONS}

Phase shift dynamics on coral reefs seem to be characterized by multiple drivers and multiple outcomes. The occurrence of coral-macroalgae phase shifts is now widely recognized and supported by numerous robust case studies reporting the often abrupt nature of the shift in relation to its persistence over time (Hughes 1994, Hunter \& Evans 1995, Ledlie et al. 2007). Our review indicates that corallimorpharian, soft coral, sponge and sea urchin dominated reefs can also constitute alternative states as a result of phase shifts. Although many of the reports of transitions to these alternative communities (Table 1) are anecdotal or lack replication over time, there are cases where long-term data corroborates the occurrence of such phase shifts. Extensive decreases in coral cover coinciding with 
substantial increases in soft coral, corallimorpharian and sponge abundances at the Aldabra Atoll, Eilat Coral Nature Reserve and Channel Cay, respectively, have persisted for several years and show no signs of reversal (Fig. 2). At Uva Island, the hyperabundant sea urchin Diadema mexicanum during the 1980s and mid-1990s has resulted in long lasting negative effects on the net carbonate accretion of the reef.

Management actions that correctly include phase shift mitigation in their agenda could ultimately be misdirected if their scientific basis does not take into account the potential range of alternative states. For example, increasing the biomass of herbivorous fishes and sea urchins has been promoted as a management strategy to avoid phase shifts (e.g. Bellwood et al. 2004, Carpenter \& Edmunds 2006). Although certainly effective in preventing coral-macroalgae shifts, it might not prevent phase shifts to other alternative states. High abundances of the grazing sea urchin Echinometra viridis kept macroalgae at bay on the Channel Cay reefs, but they did not prevent the phase shift to sponge dominance (Fig. 2). On Mediterranean rocky reefs, sea urchins may facilitate increased abundance of the bioeroding sponge Cliona viridis by removing fleshy macroalgae that are potential competitors of the sponge (Cebrian \& Uriz 2006). Hence, management of coral reefs requires an understanding of the conditions under which phase shifts to different states are likely to occur, and of the mechanisms that underlie the positive feedback loops that support hysteresis.

Acknowledgements. The authors thank J. S. Eklöf, J. Norberg, P. Lundberg, T. P. Hughes and M. Löf for valuable comments on an earlier version of this article. M.N. is financed by a research grant from the Swedish International Developmental Agency (SIDA). C.F.'s contribution is supported by the Swedish Research Council Formas (Formel-Exc grant) and the Foundation for Strategic Environmental Research (Mistra).

\section{LITERATURE CITED}

Alino PM, Sammarco PW, Coll JC (1992) Competitive strategies in soft corals (Coelenterata, Octocorallia). IV. Environmentally induced reversals in competitive superiority. Mar Ecol Prog Ser 81:129-145

Antonius A, Ballesteros E (1998) Epizoism: a new threat to coral health in Caribbean reefs. Rev Biol Trop 46:145-156

> Aronson RB, Precht WF (2001) White-band disease and the changing face of Caribbean coral reefs. Hydrobiologia 460:25-38

Aronson RB, Precht WF, Macintyre IG (1998) Extrinsic control of species replacement on a Holocene reef in Belize: the role of coral disease. Coral Reefs 17:223-230

Aronson RB, Precht WF, Macintyre IG, Murdoch TJT (2000) Ecosystems: coral bleach-out in Belize. Nature 405:36

Aronson RB, Precht WF, Toscano MA, Koltes KH (2002) The 1998 bleaching event and its aftermath on a coral reef in Belize. Mar Biol 141:435-447
Aronson RB, MacIntyre IG, Wapnick CM, O'Neill MW (2004) Phase shifts, alternative states, and the unprecedented convergence of two reef systems. Ecology 85:1876-1891

Atrigenio MP, Aliño PM (1996) Effects of the soft coral Xenia puertogalerae on the recruitment of scleractinian corals. J Exp Mar Biol Ecol 203:179-189

Bak RPM (1987) Effects of chronic oil pollution on a Caribbean coral reef. Mar Pollut Bull 18:534-539

> Bak RPM, Lambrechts DYM, Joenje M, Nieuwland G, Van Veghel MLJ (1996) Long-term changes on coral reefs in booming populations of a competitive colonial ascidian. Mar Ecol Prog Ser 133:303-306

Bellwood DR, Hughes TP, Folke C, Nyström M (2004) Confronting the coral reef crisis. Nature 429:827-833

Benayahu Y (1997) A review of three alcyonacean families (Octocorallia) from Guam. Micronesica 30:207-244

Benayahu Y, Loya Y (1977) Space partitioning by stony corals, soft corals and benthic algae on the coral reefs of the northern Gulf of Eilat (Red Sea). Helgol Wiss Meeresunters 30:362-382

Benayahu Y, Jeng MS, Perkol-Finkel S, Dai CF (2004) Soft corals (Octocorallia: Alcyonacea) from Southern Taiwan. II. Species diversity and distributional patterns. Zool Stud 43:548-560

$>$ Box SJ, Mumby PJ (2007) Effect of macroalgal competition on growth and survival of juvenile Caribbean corals. Mar Ecol Prog Ser 342:139-149

Bradbury RH, Mundy C (1989) Large-scale shifts in biomass of the Great Barrier Reef ecosystem. In: Sherman K, Alexander LM (eds) Biomass yields and geography of large marine ecosystems. Westview Press, Washington D.C., p 143-167

Bruno JF (2007) Regional decline of coral cover in the IndoPacific: timing, extent, and subregional comparisons. PLoS One 2:e711

Buckley R, Stobart B, Downing N, Teleki K (2004) Report on the 2004 Aldabra Marine Programme Research, Vol, Aldabra Marine Programme Phase V. Cambridge Coastal Research Unit report, University of Cambridge

Carpenter RC (1986) Partitioning herbivory and its effects on coral reef algal communities. Ecol Monogr 56:345-363

Carpenter RC, Edmunds PJ (2006) Local and regional scale recovery of Diadema promotes recruitment of scleractinian corals. Ecol Lett 9:268-277

> Cebrian E, Uriz MJ (2006) Grazing on fleshy seaweeds by sea urchins facilitates sponge Cliona viridis growth. Mar Ecol Prog Ser 323:83-89

> Chadwick NE (1987) Interspecific aggressive behavior of the corallimorpharian Corynactis californica (Cnidaria, Anthozoa) - effects on sympatric corals and sea-anemones. Biol Bull 173:110-125

Chadwick-Furman NE, Spiegel M (2000) Abundance and clonal replication in the tropical corallimorpharian Rhodactis rhodostoma. Invertebr Biol 119:351-360

Chadwick-Furman NE, Spiegel M, Nir I (2000) Sexual reproduction in the tropical corallimorpharian Rhodactis rhodostoma. Invertebr Biol 119:361-369

Chen CA, Dai CF (2004) Local phase shift from Acroporadominant to Condylactis-dominant community in the Tiao-Shi Reef, Kenting National Park, southern Taiwan. Coral Reefs 23:508

Chou LM, Yamazato K (1990) Community structure of coral reefs within the vicinity of Motubu and Sesoko (Okinawa) and the effects of human and natural influences. Galaxea 9:9-75

deYoung B, Barange M, Beaugrand G, Harris R, Perry RI, Scheffer M, Werner F (2008) Regime shifts in marine eco- 
systems: detection, prediction and management. Trends Ecol Evol 23:402-409

Dinesen ZD (1983) Patterns in the distribution of soft corals across the central Great Barrrier Reef. Coral Reefs 1: 229-236

> Done TJ (1992) Phase shifts in coral reef communities and their ecological significance. Hydrobiologia 247:121-132

Done TJ (1999) Coral community adaptability to environmental change at the scales of regions, reefs and reef zones. Am Zool 39:66-79

Dubinsky Z, Stambler N (1996) Marine pollution and coral reefs. Glob Change Biol 2:511-526

Eakin CM (1996) Where have all the carbonates gone? A model comparison of calcium carbonate budgets before and after the 1982-1983 El Niño at Uva Island in the eastern Pacific. Coral Reefs 15:109-119

Eakin CM (2001) A tale of two ENSO events: carbonate budgets and the influence of two warming disturbances and intervening variability, Uva Island, Panama. Bull Mar Sci 69:171-186

Endean R, Cameron AM, Devantier LM (1988) Acanthaster planci predation on massive corals: the myth of rapid recovery of devastated reefs. Proc 6th Int Coral Reef Symp 2:143-148

Fabricius KE (1998) Reef invasion by soft corals: which taxa and which habitats? In: Greenwood JG, Hall NJ (eds) Proc ACRS 75th Anniv Conf. School of Marine Science, University of Queensland, Brisbane, p 77-90

Fishelson L (1970) Littoral fauna of the Red Sea: the population of nonscleractinian anthozoans of shallow waters of the Red Sea (Eilat). Mar Biol 6:106-116

Folke C, Carpenter S, Walker B, Scheffer M, Elmqvist T, Gunderson L, Holling CS (2004) Regime shifts, resilience, and biodiversity in ecosystem management. Annu Rev Ecol Evol Syst 35:557-581

Fox HE, Pet JS, Dahuri R, Caldwell RL (2003) Recovery in rubble fields: long-term impacts of blast fishing. Mar Pollut Bull 46:1024-1031

- Gardner TA, Cote IM, Gill JA, Grant A, Watkinson AR (2003) Long-term region-wide declines in Caribbean corals. Science 301:958-960

Glynn PW (1985) Corallivore population sizes and feeding effects following El Niño (1982-83) associated coral mortality in Panama. Proc 5th Int Coral Reef Symp 4:183-188

Glynn PW (1997) Bioerosion and coral-reef growth. In: Birkeland C (ed) Life and death of coral reefs. Chapman \& Hall, New York, p 95

- Graham NAJ, Wilson SK, Jennings S, Polunin N, Bijoux JP, Robinson J (2006) Dynamic fragility of oceanic coral reef ecosystems. Proc Natl Acad Sci USA 103:8425-8429

Halpern BS, Walbridge S, Selkoe KA, Kappel CV and others (2008) A global map of human impact on marine ecosystems. Science 319:948-952

Harvell CD, Mitchell CE, Ward JR, Altizer S, Dobson AP, Ostfeld RS, Samuel MD (2002) Climate warming and disease risks for terrestrial and marine biota. Science 296: $2158-2162$

Hatcher BG (1984) A maritime accident provides evidence for alternate stable states in benthic communities on coral reefs. Coral Reefs 3:199-204

Hill MS (1998) Spongivory on Caribbean reefs releases corals from competition with sponges. Oecologia 117:143-150

> Hoegh-Guldberg O, Mumby PJ, Hooten AJ, Steneck RS and others (2007) Coral reefs under rapid climate change and ocean acidification. Science 318:1737-1742

> Holmes KE, Edinger EN, Hariyadi, Limmon GV, Risk MJ (2000) Bioerosion of live massive corals and branching coral rubble on Indonesian coral reefs. Mar Pollut Bull 40: 606-617

Hughes TP (1994) Catastrophes, phase-shifts, and large-scale degradation of a Caribbean coral reef. Science 265: $1547-1551$

Hughes TP, Baird AH, Bellwood DR, Card M and others (2003) Climate change, human impacts, and the resilience of coral reefs. Science 301:929-933

> Hughes TP, Bellwood DR, Folke C, Steneck RS, Wilson JR (2005) New paradigms for supporting resilience of marine ecosystems. Trends Ecol Evol 20:380-386

- Hughes TP, Rodrigues MJ, Bellwood DR, Ceccarelli D and others (2007) Phase shifts, herbivory, and the resilience of coral reefs to climate change. Curr Biol 17:360-365

Hunter CL, Evans CW (1995) Coral reefs in Kaneohe Bay, Hawaii-two centuries of western influence and two decades of data. Bull Mar Sci 57:501-515

Idjadi J, Lee S, Bruno J, Precht W, Allen-Requa L, Edmunds P (2006) Rapid phase-shift reversal on a Jamaican coral reef. Coral Reefs 25:209-211

IPCC (Intergovernmental Panel on Climate Change) (2007) Solomon S, Qin D, Manning M, Chen Z and others (eds) Climate change 2007: the physical science basis. Contribution of Working Group I to the Fourth Assessment Report of the Intergovernmental Panel on Climate Change. Cambridge University Press, Cambridge

> Jackson JBC (1997) Reefs since Columbus. Coral Reefs 16: S23-S32

Knowlton N (1992) Thresholds and multiple stable states in coral reef community dynamics. Am Zool 32:674-682

> Kuffner IB, Walters LJ, Becerro MA, Paul VJ, Ritson-Williams R, Beach KS (2006) Inhibition of coral recruitment by macroalgae and cyanobacteria. Mar Ecol Prog Ser 323: 107-117

Kuguru BL, Mgaya YD, Ohman MC, Wagner GM (2004) The reef environment and competitive success in the Corallimorpharia. Mar Biol 145:875-884

> Kuguru BL, Winters G, Beer S, Santos SR, Chadwick NE (2007) Adaptation strategies of the corallimorpharian Rhodactis rhodostoma to irradiance and temperature. Mar Biol 151:1287-1298

Kuguru B, Chadwick NE, Achituv Y, Zandbank K, Tchernov D (2008) Mechanisms of habitat segregation between corallimorpharians: photosynthetic parameters and Symbiodinium types. Mar Ecol Prog Ser 369:115-129

> Langmead O, Chadwick-Furman NE (1999) Marginal tentacles of the corallimorpharian Rhodactis rhodostoma. 1. Role in competition for space. Mar Biol 134:479-489

Ledlie MH, Graham NAJ, Bythell JC, Wilson SK, Jennings S, Polunin NVC, Hardcastle J (2007) Phase shifts and the role of herbivory in the resilience of coral reefs. Coral Reefs 26: 641-653

> Lesser MP, Bythell JC, Gates RD, Johnstone RW, HoeghGuldberg O (2007) Are infectious diseases really killing corals? Alternative interpretations of the experimental and ecological data. J Exp Mar Biol Ecol 346:36-44

- Lopez-Victoria M, Zea S (2005) Current trends of space occupation by encrusting excavating sponges on Colombian coral reefs. PSZNI: Mar Ecol 26:33-41

Lopez-Victoria M, Zea S, Weil E (2006) Competition for space between encrusting excavating Caribbean sponges and other coral reef organisms. Mar Ecol Prog Ser 312:113-121

Loya Y (2004) The coral reefs of Eilat-past, present and future: three decades of coral community structure studies. In: Rosenberg E, Loya Y (eds) Coral reef health and disease. Springer-Verlag, Berlin, p 29

Maida M, Sammarco PW, Coll JC (1995) Effects of soft corals 
on scleractinian coral recruitment. I: Directional allelopathy and inhibition of settlement. Mar Ecol Prog Ser 121: 191-202

Maliao R, Turingan R, Lin J (2008) Phase-shift in coral reef communities in the Florida Keys National Marine Sanctuary (FKNMS), USA. Mar Biol 154:841-853

Maragos JE, Evans C, Holthus P (1985) Reef corals in Kaneohe bay 6 years before and after termination of sewage discharges. Proc 5th Int Coral Reef Symp 4:189-194

McClanahan TR (1995) A coral reef ecosystem fisheries model-impacts of fishing intensity and catch selection on reef structure and processes. Ecol Modell 80:1-19

McClanahan TR, Mutere JC (1994) Coral and sea-urchin assemblage structure and interrelationships in Kenyan reef lagoons. Hydrobiologia 286:109-124

> McClanahan TR, Muthiga NA (1998) An ecological shift in a remote coral atoll of Belize over 25 years. Environ Conserv 25:122-130

McClanahan TR, Shafir SH (1990) Causes and consequences of sea-urchin abundance and diversity in Kenyan coralreef lagoons. Oecologia 83:362-370

McClanahan TR, Bergman K, Huitric M, McField M, Elfwing T, Nyström M, Nordemar I (2000) Response of fishes to algae reduction on Glovers Reef, Belize. Mar Ecol Prog Ser 206:273-282

McClanahan T, Polunin N, Done T (2002) Ecological states and the resilience of coral reefs. Conserv Ecol 6:18

> McCook LJ (1999) Macroalgae, nutrients and phase shifts on coral reefs: scientific issues and management consequences for the Great Barrier Reef. Coral Reefs 18: 357-367

- McManus JW, Polsenberg JF (2004) Coral-algal phase shifts on coral reefs: ecological and environmental aspects. Prog Oceanogr 60:263-279

Mora C (2008) A clear human footprint in the coral reefs of the Caribbean. Proc R Soc Lond B Biol Sci 275:767-773

Muhando CA, Mohammed M (2002) Coral reef benthos and fisheries in Tanzania before and after the 1998 bleaching and mortality event. West Indian Ocean J Mar Sci 1:43-52

Muhando CA, Kuguru BL, Wagner GM, Mbije NE, Ohman MC (2002) Environmental effects on the distribution of corallimorpharians in Tanzania. Ambio 31:558-561

Mumby PJ (2006) The impact of exploiting grazers (Scaridae) on the dynamics of Caribbean coral reefs. Ecol Appl 16: 747-769

Mumby PJ, Hastings A (2008) The impact of ecosystem connectivity on coral reef resilience. J Appl Ecol 45:854-862

Mumby PJ, Harborne AR, Williams J, Kappel CV and others (2007a) Trophic cascade facilitates coral recruitment in a marine reserve. Proc Natl Acad Sci USA 104:8362-8367

Mumby PJ, Hastings A, Edwards HJ (2007b) Thresholds and the resilience of Caribbean coral reefs. Nature 450:98-101

> Nagelkerken I, Roberts CM, van der Velde G, Dorenbosch M, van Riel MC, Cocheret de la Morinière E, Nienhuis PH (2002) How important are mangroves and seagrass beds for coral-reef fish? The nursery hypothesis tested on an island scale. Mar Ecol Prog Ser 244:299-305

Ninio R, Meekan M, Done T, Sweatman H (2000) Temporal patterns in coral assemblages on the Great Barrier Reef from local to large spatial scales. Mar Ecol Prog Ser 194: 65-74

Nishihira M, Yamazoto K (1974) Human interference with the coral reef community and Acanthaster infestation of Okinawa. Proc 2nd Int Coral Reef Symp:577-590

> Nyström M, Folke C (2001) Spatial resilience of coral reefs. Ecosystems 4:406-417

Nyström M, Folke C, Moberg F (2000) Coral reef disturbance and resilience in a human-dominated environment. Trends Ecol Evol 15:413-417

Nyström M, Graham NAJ, Lokrantz J, Norström A (2008) Capturing the cornerstones of coral reef resilience: linking theory to practice. Coral Reefs 27:795-809

O'Neill R (1998) Recovery in complex ecosystems. J Aquat Ecosyst Health 6:181-187

Obura D (2002) Status of coral reefs in East Africa. In: Lindén O, Souter D, Wilhelmson D, Obura D (eds) Coral reef degradation in the Indian Ocean: status report 2002. CORDIO, Department of Biology and Environmental Science, University of Kalmar, Kalmar, p 15

Ostrander GK, Armstrong KM, Knobbe ET, Gerace D, Scully EP (2000) Rapid transition in the structure of a coral reef community: the effects of coral bleaching and physical disturbance. Proc Natl Acad Sci USA 97:5297-5302

Pawlik JR, Steindler L, Henkel TP, Beer S, Ilan M (2007) Chemical warfare on coral reefs: sponge metabolites differentially affect coral symbiosis in situ. Limnol Oceanogr 52:907-911

Petraitis PS, Latham RE (1999) The importance of scale in testing the origins of alternative community states. Ecology 80:429-442

Rajasuriya A, Karunarathna C (2000) Post-bleaching status of the reefs of Sri Lanka. In: Souter D, Obura D, Lindén O (eds) Coral reef degradation in the Indian Ocean: Status report 2000. CORDIO, Department of Biology and Environmental Science, University of Kalmar, Kalmar, p 54

Reinicke GB, van Ofwegen LP (1999) Soft corals (Alcyonacea: Octocorallia) from shallow water in the Chagos Archipelago: species assemblages and their distribution. In: Sheppard CRC, Seaward MRD (eds) Ecology of the Chagos Archipelago. Linn Soc Occasional Pub 2:67-85

Ridzwan RA (1993) Recovery process of coral communities following the crown-of-thorns starfish, Acanthaster planci, infestations on the east coast islands of peninsular Malaysia. PhD thesis, University of Newcastle upon Tyne

Riegl B, Piller WE (1999) Coral frameworks revisited-reefs and coral carpets in the northern Red Sea. Coral Reefs 18: 241-253

Rinkevich B, Loya Y (1977) Harmful effects of chronic oil pollution on a Red Sea scleractinian coral population. Proc 3rd Int Coral Reef Symp 2:585-591

Robinson DE (1971) Observations on Fijian coral reefs and the crown-of-thorns starfish. J R Soc NZ 1:99-112

Rogers CS, Miller J (2006) Permanent 'phase shifts' or reversible declines in coral cover? Lack of recovery of two coral reefs in St. John, US Virgin Islands. Mar Ecol Prog Ser 306:103-114

Rose CS, Risk MJ (1985) Increase in Cliona delitrix infestation of Montastrea cavernosa heads on an organically polluted portion of the Grand Cayman fringing reef. PSZNI Mar Ecol 6:345-363

Rützler K (2002) Impact of crustose clionid sponges on Caribbean reef corals. Acta Geol Hisp 37:61-72

Rützler K, Diaz MC, van Soest RWM, Zea S, Smith KP, Alvarez B, Wulff J (2000) Diversity of sponge fauna in mangrove ponds, Pelican Cays, Belize. Atoll Res Bull 476:229-248

Sammarco PW, Coll JC, Barre S, Willis B (1983) Competitive strategies of soft corals (Coelenterata: Octocorallia): allelopathic effects on selected scleractinian corals. Coral Reefs $1: 173-178$

Scheffer M, Carpenter S, Foley JA, Folke C, Walker B (2001) Catastrophic shifts in ecosystems. Nature 413:591-596

Shulman MJ, Robertson DR (1996) Changes in the coral reefs of San Blas, Caribbean Panama: 1983 to 1990. Coral Reefs 15:231-236 
Smith JE, Shaw M, Edwards RA, Obura D and others (2006) Indirect effects of algae on coral: algae-mediated, microbe-induced coral mortality. Ecol Lett 9:835-845

Stobart B, Buckley R, LeClair L, Teleki K, Downing N, Souter D, Callow M (2002) Aldabra: monitoring the path to recovery. In: Lindén O, Souter D, Wilhelmson D, Obura D (eds) Coral degradation in the Indian Ocean: status report 2002. CORDIO, Department of Biology and Environmental Science, University of Kalmar, Kalmar, p 232

Stobart B, Teleki K, Buckley R, Downing N, Callow M (2005) Coral recovery at Aldabra Atoll, Seychelles: five years after the 1998 bleaching event. Philos Trans R Soc A 363: 251-255

Suding KN, Gross KL, Houseman GR (2004) Alternative states and positive feedbacks in restoration ecology. Trends Ecol Evol 19:46-53

Szmant AM (2002) Nutrient enrichment on coral reefs: Is it a major cause of coral reef decline? Estuaries 25:743-766

Tanner JE (1995) Competition between scleractinian corals and macroalgae - an experimental investigation of coral growth, survival and reproduction. J Exp Mar Biol Ecol 190:151-168

Teleki K, Downing N, Stobart B, Buckley R (2000) The status of the Aldabra Atoll coral reefs and fishes following the 1998 coral bleaching event. In: Souter D, Obura D, Lindén $\mathrm{O}$ (eds) Coral reef degradation in the Indian Ocean: status report 2000. CORDIO, Department of Biology and Environmental Science, University of Kalmar, Kalmar, p 114

Tilman D (1999) Global environmental impacts of agricultural expansion: the need for sustainable and efficient practices. Proc Natl Acad Sci USA 96:5995-6000

Editorial responsibility: Charles Birkeland,

Honolulu, Hawaii, USA
Tkachenko KS, Wu BJ, Fang LS, Fan TY (2007) Dynamics of a coral reef community after mass mortality of branching Acropora corals and an outbreak of anemones. Mar Biol 151:185-194

van Nes EH, Scheffer M (2005) Implications of spatial heterogeneity for catastrophic regime shifts in ecosystems. Ecology 86:1797-1807

Ward-Paige CA, Risk MJ, Sherwood OA, Jaap WC (2005) Clionid sponge surveys on the Florida reef tract suggest land-based nutrient inputs. Mar Pollut Bull 51:570-579

Weil E, Hernandez-Delgado EA, Bruckner AW, Ortiz AL, Nemeth M, Ruiz H (2002) Distribution and status of Acroporid coral (Scleractinia) populations in Puerto Rico. In: Bruckner AW (ed) NOAA Tech Memo NMFS-OPR-24, Silver Spring, MD, p 71-98

Wilkinson CR (ed) (2004) Status of coral reefs of the world: 2004, Vol. 1. Australian Institute of Marine Science, Townsville

Williams EH, Bartels PJ, Bunkley-Williams L (1999) Predicted disappearance of coral-reef ramparts: a direct result of major ecological disturbances. Glob Change Biol 5:839-845

Williams ID, Polunin NVC, Hendrick VJ (2001) Limits to grazing by herbivorous fishes and the impact of low coral cover on macroalgal abundance on a coral reef in Belize. Mar Ecol Prog Ser 222:187-196

Work TM, Aeby GS, Maragos JE (2008) Phase shift from a coral to a corallimorph-dominated reef associated with a shipwreck on Palmyra Atoll. PLoS One 3:e2989

Wulff J (2000) Sponge predators may determine differences in sponge fauna between 2 sets of mangrove cays, Belize barrier reef. Atoll Res Bull 477:249-263

Submitted: September 11, 2008; Accepted: November 5, 2008 Proofs received from author(s): February 3, 2009 